\title{
The role of microhabitats in structuring cave invertebrate communities in Guatemala
}

\author{
Gabrielle S.M. Pacheco (D) ${ }^{1 *}$, Marconi Souza Silva (D) ${ }^{1}$, Enio Cano (D) ${ }^{2}$, \\ and Rodrigo L. Ferreira (1D ${ }^{1}$
}

${ }^{1}$ Universidade Federal de Lavras, Departamento de Ecologia e Conservação, Setor de Biodiversidade Subterrânea, Centro de Estudos em Biologia Subterrânea, Caixa Postal 3037, CEP 37200-900, Lavras, Minas Gerais, Brasil

${ }^{2}$ Escuela de Biologia, Facultad de Ciencias Químicas y Farmacia, Universidad de San Carlos de Guatemala, Ciudad Universitaria, Zona 12, 01012, Guatemala City, Guatemala

\begin{abstract}
Several studies have tried to elucidate the main environmental features driving invertebrate community structure in cave environments. They found that many factors influence the community structure, but rarely focused on how substrate types and heterogeneity might shape these communities. Therefore, the objective of this study was to assess which substrate features and whether or not substrate heterogeneity determines the invertebrate community structure (species richness and composition) in a set of limestone caves in Guatemala. We hypothesized that the troglobitic fauna responds differently to habitat structure regarding species richness and composition than non-troglobitic fauna because they are more specialized to live in subterranean habitats. Using $30 \mathrm{~m}^{2}$ transects, the invertebrate fauna was collected and the substrate features were measured. The results showed that community responded to the presence of guano, cobbles, boulders, and substrate heterogeneity. The positive relationship between non-troglobitic species composition with the presence of guano reinforces the importance of food resources for structuring invertebrate cave communities in Guatemalan caves. Furthermore, the troglobitic species responded to different substrate features when compared to non-troglobitic species. For them, instead of the presence of organic matter, a higher variety of abiotic microhabitats seem to be the main driver for species diversity within a cave. The high specialization level of troglobitic organisms might be the reason why they respond differently to environmental conditions. The findings of this study highlight the importance of biological surveys for understanding cave biodiversity and give insights on how this biodiversity might be distributed within a cave. Conservation measures should keep in mind the target organisms and if such measures aim to protect a broad variety of organisms, then one should aim to preserve as many microhabitats and trophic resources as possible.
\end{abstract}

Keywords: $\quad$ arthropods, habitat heterogeneity, substrate composition, troglobites, Central America

Received 8 June 2020; Revised 1 September 2020; Accepted 14 September 2020

Citation: Pacheco G.S.M., Souza Silva M., Cano E. and Ferreira R.L., 2020. The role of microhabitats in structuring cave invertebrate communities in Guatemala. International Journal of Speleology, 49 (2), 161-169. Tampa, FL (USA) ISSN 0392-6672

https://doi.org/10.5038/1827-806X.49.2.2333

\section{INTRODUCTION}

Patterns of species distribution and factors structuring communities have always been central subjects for ecological studies (Dunson \& Travis, 1991; Kolasa \& Pickett, 1991; Cushman \& McGarigal, 2004; Steinitz et al., 2006; Talley, 2007). For caves, understanding these patterns and factors is fundamental for conservation purposes, as the organisms that inhabit these environments are known to be relatively sensitive to many stressors, both natural and anthropic (Howarth, 1983; Mammola, 2019; Mammola et al., 2019).
Several studies have tried to elucidate the main environmental factors driving the invertebrate community structure (species richness and composition) in cave environments. The main factors highlighted as important are seasonality (Tobin et al., 2013; Mammola et al., 2015; Bento et al., 2016; Lunghi et al., 2017; Kozel et al., 2019), lithology (Souza-Silva et al., 2011b), landscape structure (Christman et al., 2016; Pellegrini et al., 2016; Mammola \& Leroy, 2017), distance from cave entrance (Ferreira \& Martins, 1998; Prous et al., 2004; Tobin et al., 2013; Kozel et al., 2019), linear development of the cave (Simões et al., 2015; Pellegrini \& Ferreira, 2016), presence 
of water (Simões et al., 2015), resource availability (Ferreira \& Martins, 1998; Gers, 1998; Jaffé et al., 2016; Ferreira, 2019), microclimate (Mammola et al., 2015; Lunghi et al., 2019) and speleogenesis (Sendra et al., 2014; Jiménez-Valverde et al., 2017). However, rare examples focused on how the substrate types and substrate heterogeneity might be shaping these communities within a cave (Prous et al., 2015; Pellegrini et al., 2016; Zepon \& Bichuette, 2017).

It is currently known that invertebrates have a preferential selection of microhabitats inside the caves (Culver \& Pipan, 2009; Moseley, 2009; SouzaSilva \& Ferreira, 2009; Mammola et al., 2016). Such preferences for specific types of microhabitats are due to a variety of reasons, including behavioral, physiological, and morphological adaptations (Howarth, 1983; Zepon \& Bichuette, 2017). These microhabitats encompass different abiotic (lakes, water bodies, puddles, types of substrates, and rocks of different textures and sizes) and biotic (roots, guano, vegetal debris, and carcasses) features (Ferreira et al., 2007; Culver \& Pipan, 2009; Souza-Silva et al., 2011a; Simões et al., 2015). Therefore, the habitat heterogeneity increases the microhabitat availability for the invertebrate fauna (Zagmajster et al., 2018).

Organisms that are specialized to live in caves (i.e., troglobites) are, in many cases, rare and endemic. They are vulnerable to stochastic events, environmental disturbances, and anthropic impacts (Gibert \& Deharveng, 2002; Culver \& Pipan, 2009, Mammola et al., 2019). Furthermore, underground life provides environmental ecosystem services, such as the decomposition of organic matter, pollination, and insect control, features that have been attracting the attention of conservation researchers (Culver \& Pipan, 2009, Mammola et al., 2019).

Guatemala has a variety of caves in quite distinct regions, although in a small territory. There is a reasonable amount of scientific work on the taxonomy of cave invertebrates in the country (see Reddell, 1981; Strinati, 1994; Reddell \& Veni, 1996), but there is a noticeable gap when it comes to their ecology. This study, therefore, aimed to evaluate which substrate features influence the invertebrate community structure and how the substrate heterogeneity influences the invertebrate community structure in a set of Guatemalan caves. We hypothesized that places with higher substrate heterogeneity have higher species richness than places with lower substrate heterogeneity and that the troglobitic species respond differently to the habitat structure than non-troglobitic species because they are more specialized to live in subterranean habitats.

\section{MATERIALS AND METHODS}

\section{Study area}

Guatemala is a tropical country that features several environmental conditions within a relatively small geographic area (Strinati, 1994). With three different climate types (Equatorial Monsoon, Equatorial savannah with dry winter and Warm temperate climate with dry winter) (Kottek et al., 2006; Peel et al., 2007), the country features an average of 3,000 to $4,000 \mathrm{~mm}$ of rain every year, with rains concentrated between May and October (Kottek et al., 2006; Peel et al., 2007). There is a set of limestone karstic landscapes that cover about one-third of its area. The karstic landscapes from Guatemala are divided into four main geologic domains, mostly in the northern portion of the country: Huehuetenango, Alta Verapaz, Izabal, and Petén (Strinati, 1994). This study was conducted in 10 limestone caves from two of these karstic regions: Alta Verapaz and Petén, on a region known as Northern Lowlands (Fig. 1; Table 1).

The caves sampled had different characteristics. They varied as to the presence/absence of water bodies, dripping activity, and the number of entrances. The caves also had different uses. Furthermore, most of the caves had remains of Mayan rituals, such as clay pots, candles, bones, and traces of bonfires.

Cueva Aktun Kan, Cúpula de los Murciélagos, Ventanas de Seguridád, Cueva Blanca, and Gruta de Lanquín have different levels of touristic activity. Cuva Aktun Kan and Gruta de Lanquín are located in places with high international tourism influx and are, therefore, highly explored touristically with almost no control whatsoever. The other touristic caves, in the other hand, are located in an area predominantly visited by local tourists and have more controlled adventure tourism. Cueva del Venado, Cueva el Rostro, Cueva de Arcilla, Cueva Coral, and Cueva Chipix do not have touristic activity.

\section{Field procedures}

All data were collected in $30 \mathrm{~m}^{2}(10 \mathrm{~m} \times 3 \mathrm{~m})$ transects throughout the caves. All transects were placed at least $25 \mathrm{~m}$ from each other. The number of transects per cave ranged from one to eight (Table 1), with a total of 25 transects. In this study, the number of transects per cave was not standardized for logistical reasons, therefore it was best suited to use the transects as sampling units instead of the caves. Since there are no studies that state how far apart cave sampling units should be in order to assume independency, we have assumed a $25 \mathrm{~m}$ distance between transects as a measure of independence among transects, especially considering the highly heterogeneous substrates sampled within each cave.

The invertebrate fauna was collected manually in the transects through direct intuitive searches (Wynne et al., 2019) and the sampling method was exhaustive (i.e., the researchers only stopped once there were no more invertebrates to be collected or accounted for). The invertebrates were collected with the aid of brushes and tweezers and placed in vial containing a solution of $70 \%$ ethanol for further examination and identification in the laboratory. When the abundance of invertebrates of the same species in a transect was high, a few specimens were collected and the remaining individuals were accounted for in the field notebook.

Afterwards, the substrate was characterized according to a field protocol adapted from Peck et al. (2006) and Hughes and Peck (2008). This protocol consists of dividing each transect into 10 sections of 


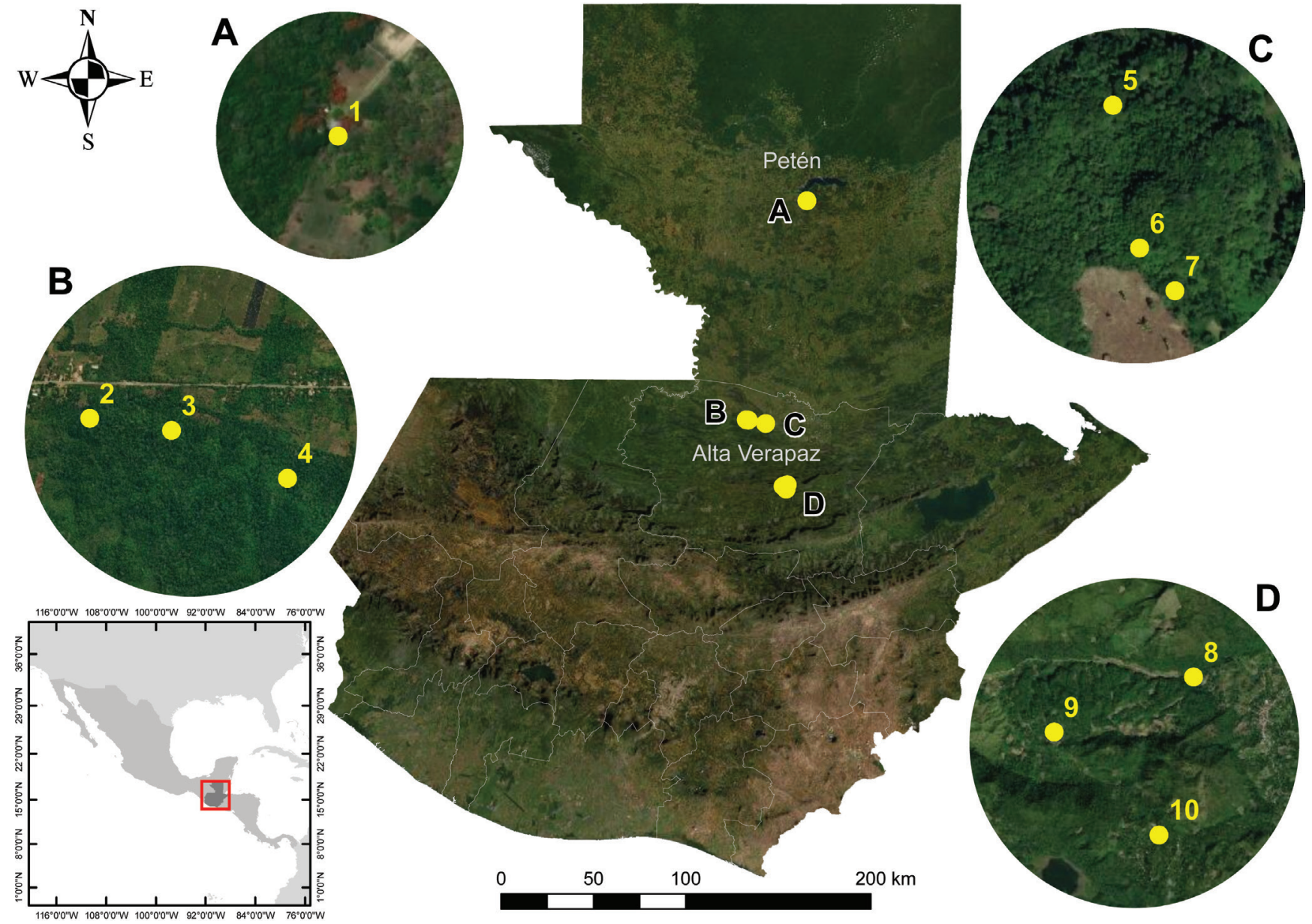

Fig. 1. Location of the ten caves sampled in Guatemala. $A=$ Petén: 1) Cueva Aktun Kan. B, $C$ and $D=$ Alta Verapaz: 2) Cúpula de los Murciélagos; 3) Cueva del Venado; 4) Ventanas de La Seguridád; 5) Cueva Blanca; 6) Cueva El Rostro; 7) Cueva de Arcilla; 8) Gruta de Lanquín; 9) Cueva Coral, and 10) Cueva Chipix.

Table 1. Cave names, coordinates UTM - Datum: WGS-84 (X, Y), altitude (Alt), and number of transects sampled in each cave (N).

\begin{tabular}{|c|c|c|c|c|c|c|c|}
\hline Cave name & Department & Municipality & $\mathbf{x}$ & $\mathbf{Y}$ & Zone & Alt (m) & $\mathbf{N}$ \\
\hline Cueva Aktun Kan & Petén & Flores & 191539 & 1871065 & $16 Q$ & 174 & 3 \\
\hline Cúpula de los Murciélagos & Alta Verapaz & Raxruhá & 801025 & 1758019 & $15 \mathrm{P}$ & 215 & 3 \\
\hline Cueva del Venado & Alta Verapaz & Raxruhá & 801412 & 1757969 & $15 \mathrm{P}$ & 218 & 3 \\
\hline Ventanas de Seguridád & Alta Verapaz & Raxruhá & 801964 & 1757753 & $15 \mathrm{P}$ & 220 & 2 \\
\hline Cueva Blanca & Alta Verapaz & Raxruhá & 811098 & 1756305 & $15 \mathrm{P}$ & 180 & 2 \\
\hline Cueva El Rostro & Alta Verapaz & Raxruhá & 811125 & 1756173 & $15 \mathrm{P}$ & 208 & 1 \\
\hline Cueva de Arcilla & Alta Verapaz & Raxruhá & 811159 & 1756134 & $15 \mathrm{P}$ & 187 & 1 \\
\hline Gruta de Lanquín & Alta Verapaz & Lanquín & 179249 & 1724774 & $16 \mathrm{P}$ & 299 & 8 \\
\hline Cueva Coral & Alta Verapaz & Lanquín & 820737 & 1723971 & $15 \mathrm{P}$ & 482 & 1 \\
\hline Cueva Chipix & Alta Verapaz & Lanquín & 178710 & 1722477 & $16 \mathrm{P}$ & 642 & 1 \\
\hline
\end{tabular}

one meter each and estimating the percentage of each substrate type. In this case: guano, roots, leaves, twigs, trunks, waterbody, water puddle, actinomycetes, fine sediment $(0.06-64 \mathrm{~mm})$, cobbles $(64-1000 \mathrm{~mm})$, boulders $(1000-4000 \mathrm{~mm})$, matrix rock (>4000 mm) and human interventions (bridges, pathways, and steps made of concrete).

Because we have chosen a visual estimation method for evaluating the substrate percentages, three steps were taken in order to minimize observer error: (i) all transects were characterized by the same person; (ii) the percentage values obtained in the 10 sections in a transect summed and divided by 10 (arithmetic mean), resulting in a single percentage value for each substrate type in the transect and (iii) these percentage ranges allocated into five categories:
$<1 \%=\mathbf{0} ; 1-5 \%=\mathbf{1} ; 5-25 \%=\mathbf{2} ; 25-50 \%=\mathbf{3} ; 50-$ $75 \%=\mathbf{4} ; 75-100 \%=\mathbf{5}$.

\section{Species identification and troglomorphisms}

Invertebrates were identified until the lowest possible taxonomic level with the aid of taxonomic keys and then grouped into morphospecies (Oliver $\&$ Beattie 1996). This approach was chosen due to a large number of new species found in caves, combined with the lack of literature and specialists on some of the taxa. Still, specimens of the taxa Acari, Diplura, Isopoda, Opiliones, Palpigradi, and Pseudoscorpiones were identified by specialists.

Specimens that featured morphologic traits that indicate adaptations to life in the cave environment were considered to be potentially troglobitic. These 
characteristics classically include the elongation of locomotor and sensory appendages, increased number of trichobothria, absence or reduction of ocular structures, body pigmentation, and wings (Barr, 1968; Hoch \& Ferreira, 2012; Novak et al., 2012).

\section{Data analysis}

To test the influence of the percentage of each substrate type (guano, roots, leaves, twigs, trunks, waterbody, water puddle, actinomycetes, fine sediment, cobbles, boulders, matrix rock, human interventions) and substrate heterogeneity on species composition and richness, Distance-Based Linear Models (DistLM) were performed in Primer-e and Permanova + Software (Anderson et al., 2008). The model selection was made using the $\mathrm{R}^{2}$ selection criterion and forward selection procedure. These models had the transects as sample units and only significant predictor variables were included in the final best models. To observe the effects on species composition, we built the resemblance matrix using the Bray Curtis similarity index with the invertebrate data transformed into the squared root, in order to mitigate the effect of large species abundances and to observe the effects on species richness, we built models using an Euclidean Distance matrix.
To test our main hypotheses, the above-cited analyses were performed for non-troglobitic species and then repeated using only troglobitic species. Significance was regarded at $\mathrm{p} \leq 0.05$.

\section{RESULTS}

A total of 10,354 specimens were registered in the 25 sampled transects. They were distributed into 38 orders, at least 78 families and 177 species, 24 of which were considered troglobites (Fig. 2 and Supplementary Material). The troglobitic fauna includes one species of Araneae (Corinnidae), one Coleoptera (Tenebrionidae), two Diplura (Campodeidae), five Collembola (four Entomobryidae and one Symphypleona), one Geophilomorpha, two Isopoda (Philosciidae and Styloniscidae), two Zygentoma (Nicoletiidae), two Opiliones (Samoidae and Stygnopsidae), four Polydesmida, and four Pseusdoscorpiones (one Bochicidae and three Chthoniidae). The highest nontroglobitic species richness was found in the transects of Gruta de Lanquín (29 spp.), Cueva Chipix (29 spp.), and Cueva Aktun Kan (28 spp.), while the highest troglobitic species richness was found in the transects of Gruta de Lanquín (6 spp.), Cueva Blanca (4 spp.), and Cueva Aktun Kan (4 spp.).

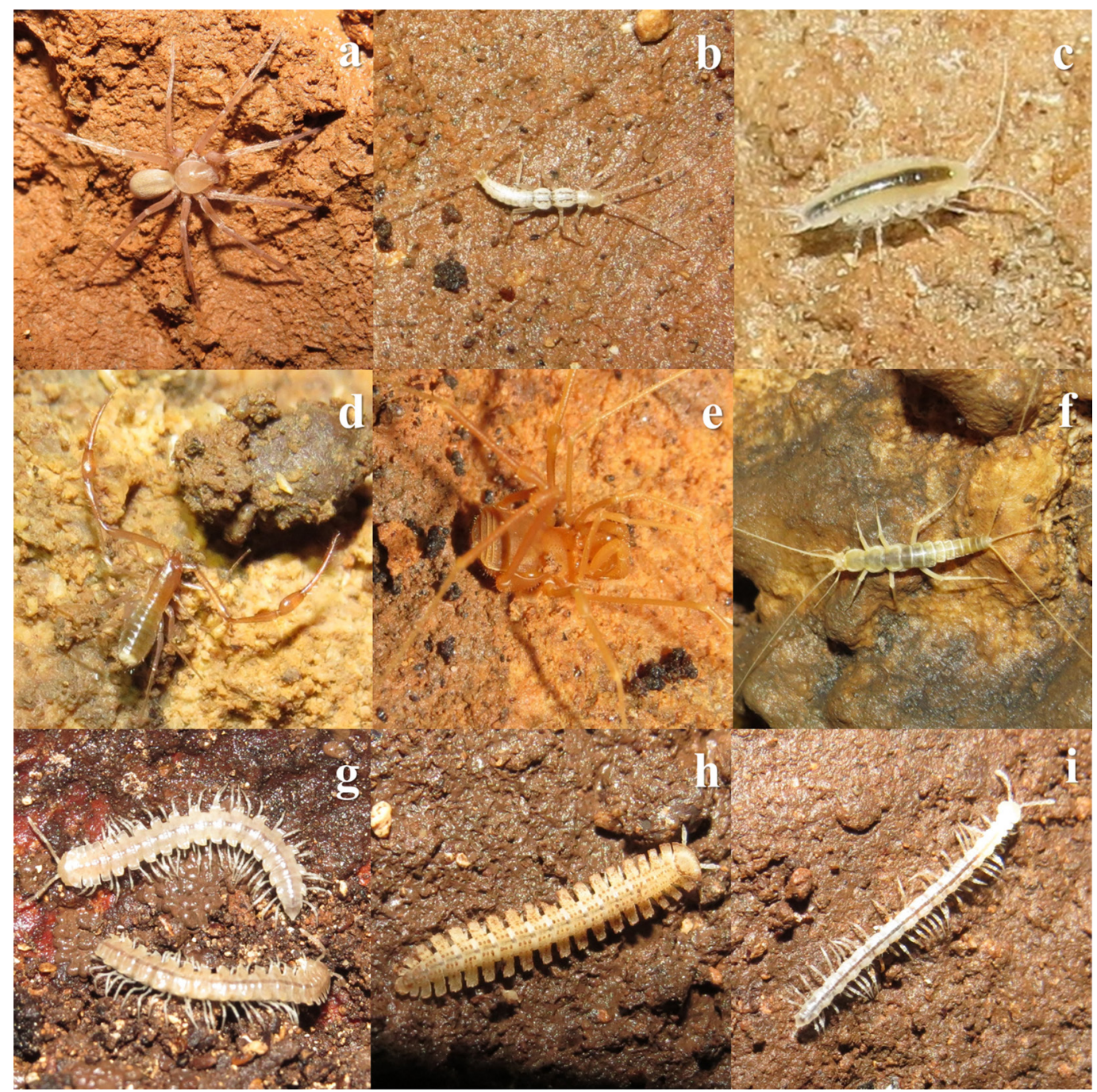

Fig. 2. Some of the troglobitic species sampled in Guatemala caves. a) Araneae (Corinnidae); b) Diplura (Campodeidae, Juxtlacampa sp. n); c) Isopoda (Styloniscidae); d) Peudoscorpiones (Ideoroncidae, Typlhoroncus guatemalensis); e) Opiliones (Stygnopsidae); f) Thysanura (Nicoletiidae, Anelpistina sp. n); g) Polydesmida (Chelodesmidae); h) Polydesmida (Pyrgodesmidae); i) Polydesmida (Paradoxosomatidae). 
The most abundant substrate type was fine sediment, followed by matrix rock, guano, cobbles, and boulders, present in $24,20,16,14$, and 11 of the 25 transects, respectively (Supplementary Material). Each transect had an average of 4.19 ( $\mathrm{sd}= \pm 1.48$ ) different types of substrates. The transects with higher substrate heterogeneity were located in Cueva Chipix (transect 10, H' = 2.008), Cueva Coral (Transect 9, $H^{\prime}=1.864$ ), and Gruta de Lanquín (transects 1 and 4, $\mathrm{H}^{\prime}=1.748$ ) (Supplementary Material).

The non-troglobitic species composition variation was best explained by the presence of guano, cobbles, and substrate heterogeneity, which explained together $23.1 \%$ of the variation on the community on the sequential tests and $27.9 \%$ of the non-troglobitic species richness variation was best explained by the substrate heterogeneity (Table 2). As for the troglobitic species, the variation in species composition was best explained in the model by the presence of boulders, substrate heterogeneity, and cobbles, totalizing $24.3 \%$ of explanation power on the model, while $20 \%$ of the troglobitic species richness variation was best explained by the presence of boulders (Table 2).

Table 2. Summary of the DistLM models describing troglobitic and non-troglobitic species composition variations

(Subs heter $=$ Substrate heterogeneity; Prop $=$ Proportin of explanation of the model; $\mathbf{R}^{2}$ adj $=\mathbf{R}$ squared adjusted).

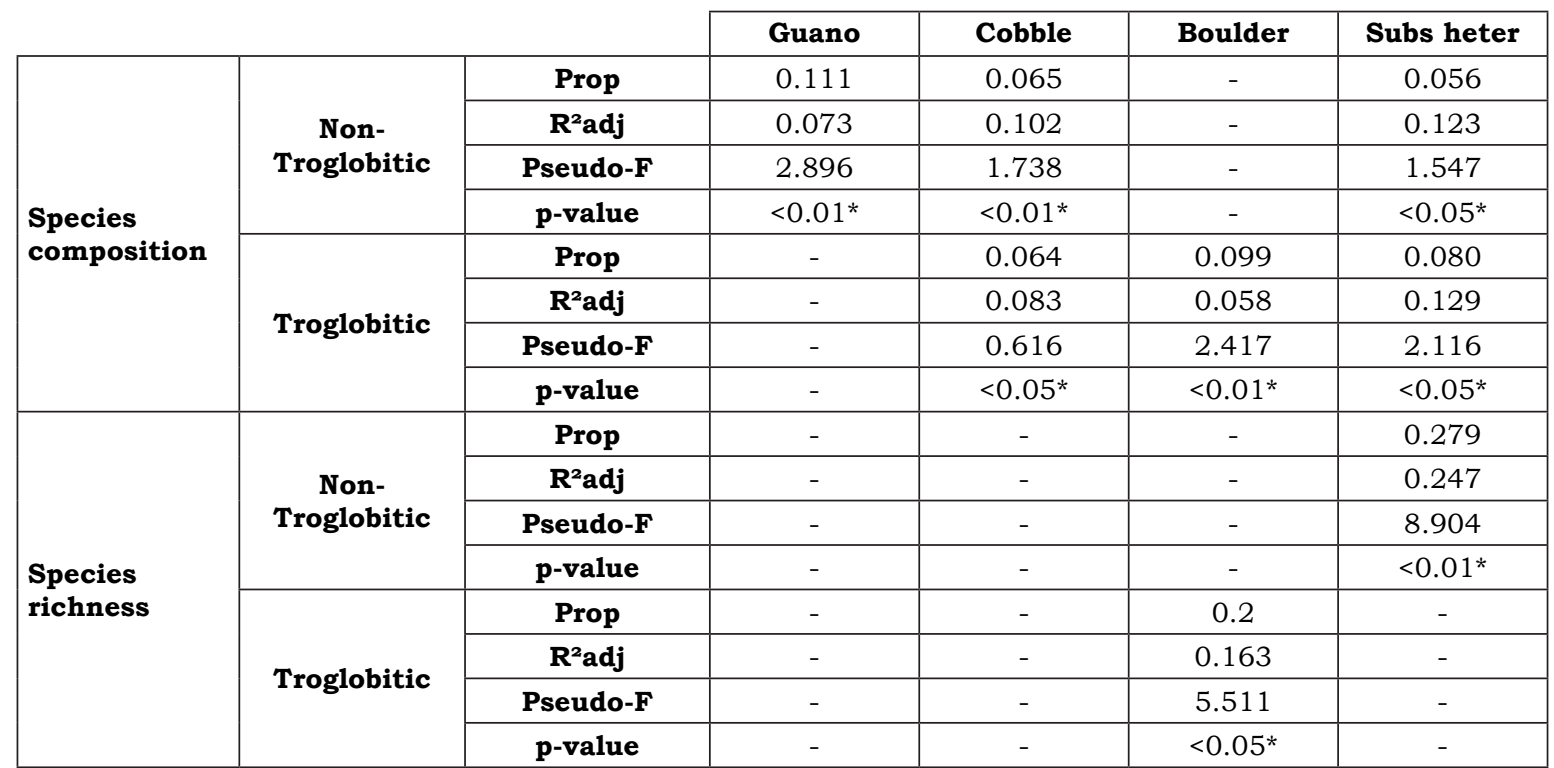

\section{DISCUSSION}

The species richness and composition found in this study are unprecedented for Guatemala. Previous studies focused mostly on descriptions of new species and thus failed to showcase the broad diversity of invertebrate species in Guatemalan caves (Barr, 1973; Gertsch, 1973; Schultz, 1977; Platnick \& Pass, 1982; Rodriguez \& Hobbs Jr, 1990; Espinasa \& Zhuang, 2009; Viana \& Ferreira, 2019) with rare exceptions (Mitchell \& Reddell, 1973; Reddell, 1981; Reddell \& Veni, 1996).

The linear models showed that the troglobitic species composition is more influenced by the substrate heterogeneity than the non-troglobitic, but only non-troglobitic species richness is influenced by substrate heterogeneity. Thus, for troglobitic species, the substrate heterogeneity might not be providing suitable habitats to a larger number of species, but instead for a larger number of individuals. This is probably a result of the high specialization of troglobitic organisms. While for the non-troglobitic fauna, the variety of substrates provides suitable habitats for an important increase in both species richness and composition.

In our study, non-troglobitic species behaved as already showed in the literature, as it is known that heterogenous habitats can shelter a larger number of species by providing more available habitats, allowing a decrease in ecological niche overlap and reducing competitive exclusion (Poulson \& Culver, 1969; Ferreira \& Souza-Silva, 2001; Tews et al., 2004; Stein et al., 2014; Pellegrini et al., 2016; Resende \& Bichuette, 2016). Environments formed by the agglomeration of gravel, for example, comprise void spaces that can provide terrestrial invertebrate species with microhabitats, food resources, protection, and refuge (Mammola et al., 2016).

Since most caves can be characterized as oligotrophic environments when compared to the surface environments (Fiser, 2019; Fong, 2019; Trontelj, 2019), the local presence of organic resources often means that these places have a higher diversity of invertebrate fauna. Several authors have already shown the importance of guano deposits and vegetal debris inside the cave environment (Decu, 1986; Gnaspini, 1989; Ferreira \& Martins, 1998; Ferreira \& Martins, 1999; Ferreira et al., 2000; Ferreira et al., 2007; Santana et al., 2010; Schneider et al., 2011). Beyond providing habitat availability, they also act as the main food sources for the lower levels of the food web, allowing the occurrence of greater species richness (Pellegrini \& Ferreira, 2012; Pellegrini \& Ferreira, 2013; Jaffé et al., 2016; Ferreira, 2019). The direct and significant relationship between non-troglobitic species composition with the presence of guano reinforces the importance of food resources for the structuring of Guatemalan cave invertebrate communities. 
The presence of guano tends to be of extreme importance in permanently dry caves (Ferreira et al., 2007; Ferreira, 2019). In this study, even though most of the caves had water bodies, the guano was still a strong structurer for the cave invertebrate communities. Here, the presence of guano seems to be more important for the invertebrates than the presence of other types of organic matter (actinomycetes and vegetal debris). The abundance of guano in a cave can eventually attract a huge variety of invertebrates, most of them non-troglobites, which can lead to the emergence and establishment of large invertebrate populations and consequently a high level of biological interactions onto it. The presence of these communities on an ephemeral resource such as guano might repel the troglobitic species, which are often more sensitive, from these habitats (Ferreira et al., 2007), although there are exceptions (Ferreira, 2019).

Accordingly, the troglobitic species seem to be influenced differently from the non-troglobitic within the caves, responding to different substrate features when compared to non-troglobitic species. For them, the presence of organic matter, regardless of its source, does not seem to be the main driver for species diversity within a cave. Instead, troglobitic species composition seems to be more related to a higher variety of abiotic microhabitats (cobbles, boulders, and substrate heterogeneity) and troglobitic species richness, to the presence of boulders. The high specialization level of troglobitic organisms might be the reason why they respond differently to environmental conditions, in this case, substrate characteristics and heterogeneity. The lack of a statistically significant relationship between troglobitic species richness and substrate heterogeneity is a sign of such specialization level since instead of filling all available ecological niches and habitats, they seek for specific conditions inside the cave environment. In other words, substrate heterogeneity can influence which troglobitic species are inhabiting a cave but not how many. Troglobitic organisms might have suffered different ecological pressures over time when compared to troglophiles and trogloxenes, hence occupying an entirely different niche. Being adapted to the dark and oligotrophic cave environment, they can inhabit places that are not tolerable for most cave dwellers (Kozel et al., 2019).

The relatively low explanatory values obtained in the linear models were expected due to the methodology chosen for this study. There is likely a range of other parameters influencing these communities. Therefore, future studies should incorporate as many variables as possible to further investigate and elucidate the main factors influencing cave invertebrate fauna.

The findings of this study highlight the importance of biological surveys for understanding cave biodiversity and give insights on how this biodiversity might be distributed within a cave. Conservation biologists should keep in mind to target as many microhabitats as possible to maximize the effectiveness of protection measures. Furthermore, it provides a scientific biological background for the creation of new parameters for the management and conservation of caves in Guatemala.

\section{ACKNOWLEDGMENTS}

The authors would like to thank the following for their efforts to make this work possible: Dr. Jack Schuster, for the support in Guatemala City. Felipe, who guided us in San Augustín de Lanquín, and introduced us to his family. L. Ázara, L. Bernardi, R.B. Pereira, A. Perez-Gonzalez, L. Rabelo, A. Sendra, A.C. Viana, and M. Villela helped with the identification of the invertebrates. M.P.A. Oliveira, and R.D. Zenni provided advice, and help with the statistical analysis. R.R. Trotta produced the artwork. We would also like to thank the reviewers who provided substantial advice to improve the manuscript. Permits to sample in Guatemala caves were granted by Consejo Nacional de Areas Protegidas (CONAP). This study was financed in part by the Coordenação de Aperfeiçoamento de Pessoal de Nivel Superior Brasil (Finance Code 001). RLF thanks the Conselho Nacional de Desenvolvimento Científico e Tecnológico (CNPq grant no. 308334/2018-3). We also thank the VALE/SA company for all support provided to Centro de Estudos em Biologia Subterrânea.

Authorship statement: RLF, MSS, and GSMP designed the research project; EC provided all infrastructure needed for the fieldwork in Guatemala; GSMP conducted all laboratory work, data analysis, and wrote the first manuscript draft; RLF, MSS, and EC revised the first draft, and helped to build the final manuscript.

\section{REFERENCES}

Anderson, M.J., Gorley R.N., Clarke K.R., 2008. PERMANOVA+ for PRIMER: Guide to software and statistical methods. Massey University, Albany Campus, Auckland: New Zealand.

Barr, T.C., 1968. Cave ecology and the evolution of troglobites. In: Dobzhansky, T., Hecht, M.K., Steere, W.C. (Eds.), Evolutionary biology. Springer, Boston, p. 35-102. https://doi.org/10.1007/978-1-4684-8094-8 2

Barr, T.C., 1973. Speocolpodes, a new genus of troglobitic beetles from Guatemala (Coleoptera: Carabidae). Psyche: A Journal of Entomology, 80, 271-276. https://doi.org/10.1155/1973/83417

Bento, D.M., Ferreira, R.L., Prous, X., Souza-Silva, M., Bellini, B.C., Vasconcellos, A., 2016. Seasonal variations in cave invertebrate communities in the semiarid Caatinga, Brazil. Journal of Cave and Karst Studies, 68, 61-71. https://doi.org/10.4311/2015LSC0111

Boyero, L. 2003. The quantification of local substrate heterogeneity in streams and its significance for macroinvertebrate assemblages. Hydrobiologia, 499, 161-168.

https://doi.org/10.1023/A:1026321331092

Christman, M.C., Doctor, D.H., Niemiller, M.L., Weary, D.J., Young, J.A., Zigler, K.S., Culver, D.C., 2016. Predicting the occurrence of cave-inhabiting fauna based on features of the earth surface environment. PLoS ONE, 11, e0160408. https://doi.org/10.1371/journal.pone.0160408

Clarke, K.R., Warwick, R.M., 2005. Primer-6 computer program. Natural Environment Research Council, Plymouth. 
Culver, D.C., Pipan, T., 2009. The biology of caves and other subterranean habitats. Oxford University Press, London, $254 \mathrm{p}$. https://doi.org/10.1093/oso/9780198820765.001.0001

Cushman, S., McGarigal, K., 2004. Patterns in the species-environment relationship depend on both scale and choice of response variables. Oikos, 105, 117-124. https://doi.org/10.1111/j.0030-1299.2004.12524.x

Decu, V. 1986. Some considerations on the bat guano synusia. Travaux de L'Institut de Spéologie "Emile Racovitza", 25, 41-51.

Dunson, W.A., Travis, J., 1991. The role of abiotic factors in community organization. The American Naturalist, 138, 1067-1091. https://doi.org/10.1086/285270

Espinasa, L., Zhuang, Z., 2009. A Cavernicolous species of the genus Anelpistina (Insecta: Zygentoma: Nicoletiidae) from Naj Tunich Cave, Petén, Guatemala. Proceedings of the Entomological Society of Washington, $111,575-580$

https://doi.org/10.4289/0013-8797-111.3.575

Ferreira, R.L, Souza-Silva, M., 2001. Biodiversity under rocks: the role of microhabitats in structuring invertebrate communities in Brazilian outcrops. Biodiversity and Conservation, 10, 1171-1183. https://doi.org/10.1023/A:1016616207111

Ferreira, R.L., 2019. Guano communities. In: White, W.B., Culver, D.C., Pipan, T. (Eds.), Encyclopedia of caves (3 $3^{\text {rd }}$ Ed.). Academic Press, p. 474-484.

https://doi.org/10.1016/B978-0-12-814124-3.00057-1

Ferreira, R.L., Martins, R.P., 1998. Diversity and distribution of spiders associated with bat guano piles in Morrinho cave (Bahia State, Brazil). Diversity and Distributions, 4, 235-241. https://www.jstor.org/stable/2999829

Ferreira, R.L., Martins, R.P., 1999. Trophic structure and natural history of bat guano invertebrate communities with special reference to Brazilian caves. Tropical Zoology, 12, 231-259. https://doi.org/10.1080/03946975.1999.10539391

Ferreira, R.L., Martins, R.P., Yanega, D., 2000. Ecology of bat guano arthropod communities in a Brazilian dry cave. Ecotropica, 6, 105-116.

Ferreira, R.L., Prous, X., Martins, R.P., 2007. Structure of bat guano communities in a dry Brazilian cave. Tropical Zoology, 20, 55-74.

Fišer, Ž., 2019. Adaptation to low food. In: White, W.B., Culver, D.C., Pipan, T. (Eds.), Encyclopedia of caves ( $3^{\text {rd }}$ Ed.). Academic Press, p. 1-7. https://doi.org/10.1016/B978-0-12-814124-3.00001-7

Fong, D.W., 2019. Food sources. In: White, W.B., Culver, D.C., Pipan, T. (Eds.), Encyclopedia of caves ( ${ }^{\text {rd }}$ Ed.). Academic Press, p. 429-434.

https://doi.org/10.1016/B978-0-12-814124-3.00051-0

Gers, C. 1998. Diversity of energy fluxes and interactions between arthropod communities: from soil to cave. Acta Oecologica, 19, 205-213. https://doi.org/10.1016/S1146-609X(98)80025-8

Gertsch, W.J., 1973. A report on cave spiders from Mexico and Central America. Bulletin of the Association for Mexican Cave Studies, 5, 141-163.

Gibert, J., Deharveng, L., 2002. Subterranean ecosystems: a truncated functional biodiversity. American Institute of Biological Sciences Bulletin, 52, 473-481. https://doi.org/10.1641/0006-3568(2002)052 [0473:SEATFB]2.0.CO;2

Gnaspini, P., 1989. Análise comparativa da fauna associada a depósitos de guano de morcegos cavernícolas no Brasil: primeira aproximação. Revista Brasileira de Entomologia, 33, 183-192.
Hoch, H., Ferreira, R.L., 2012. Ferricixius davidi gen. n., sp. n.-the first cavernicolous planthopper from Brazil (Hemiptera, Fulgoromorpha, Cixiidae). Deutsche Entomologische Zeitschrift, 59, 201-206.

https://doi.org/10.1002/mmnd.201200015

Howarth, F.G., 1983. Ecology of cave arthropods. Annual Review of Entomology, 28, 365-389.

https://doi.org/10.1146/annurev.en.28.010183.002053

Hughes, R.M., Peck, D.V., 2008. Acquiring data for large aquatic resource surveys: the art of compromise among science, logistics, and reality. Journal of the North American Benthological Society, 27, 837-859. https://doi.org/10.1899/08-028.1

Jaffé, R., Prous, X., Zampaulo, R., Giannini, T.C., Imperatriz-Fonseca, V.L., Maurity, C., Siqueira, J.O., 2016. Reconciling mining with the conservation of cave biodiversity: a quantitative baseline to help establish conservation priorities. PLoS ONE, 11, e0168348.

https://doi.org/10.1371/journal.pone.0168348

Jiménez-Valverde, A., Sendra, A., Garay, P., Reboleira, A.S.P., 2017. Energy and speleogenesis: key determinants of terrestrial species richness in caves. Ecology and Evolution, 7, 10207-10215. https://doi.org/10.1002/ece3.3558

Kolasa, J., Pickett, S.T.A. (Eds.), 1991. Ecological heterogeneity. Ecological studies. Springer, New York. https://doi.org/10.1007/978-1-4612-3062-5

Kottek, M., Grieser, J., Beck, C., Rudolf, B., Rubel, F., 2006. World map of the Köppen-Geiger climate classification updated. Meteorologische Zeitschrift, 15, 259-263. https://doi.org/10.1127/0941-2948/2006/0130

Kozel, P., Pipan, T., Mammola, S., Culver, D.C., Novak, T., 2019. Distributional dynamics of a specialized subterranean community oppose the classical understanding of the preferred subterranean habitats. Invertebrate Biology, 138, e12254. https://doi.org/10.1111/ivb.12254

Li, H., Reynolds, J.F., 1994. A simulation experiment to quantify spatial heterogeneity in categorical maps. Ecology, 75 (8), 2446-2455. https://doi.org/10.2307/1940898

Li, H., Reynolds, J.F. 1995. On definition and quantification of heterogeneity. Oikos, 73, 280-284. https://doi.org/10.2307/3545921

Lunghi, E., Manenti, R., Ficetola, G.F., 2017. Cave features, seasonality and subterranean distribution of non-obligate cave dwellers. PeerJ, 5, e3169. https://doi.org/10.7717/peerj.3169

Mammola, S., 2019. Finding answers in the dark: caves as models in ecology fifty years after Poulson and White. Ecography, 42, 1331-1351. https://doi.org/10.1111/ecog.03905

Mammola, S., Cardoso, P., Culver, D.C., Deharveng, L., Ferreira, R.L., Fiser, C., Galassi, D.M.P., Grielber, C., Halse, S., Humphreys, W.F., Isaia, M., Malard, F., Martinez, A., Moldovan, O.T., Niemiller, M.L., Pavlek, M., Reboleira, A.S.P.S., Souza-Silva, M., Teeling, E.C., Wynne, J.J., Zagnajster, M., 2019. Scientists' warning on the conservation of subterranean ecosystems. BioScience, 69, 641-650 https://doi.org/10.1093/biosci/biz064

Mammola, S., Leroy, B., 2017. Applying species distribution models to caves and other subterranean habitats. Ecography, 41, 1194-1208. https://doi.org/10.1111/ecog.03464

Mammola, S., Piano, E., Giachino, P.M., Isaia, M., 2015. Seasonal dynamics and micro-climatic preference of two Alpine endemic hypogean beetles. International Journal of Speleology, 44 (3), 239-249. https://doi.org/10.5038/1827-806X.44.3.3 
Mammola, S., Piano, E., Isaia, M., 2016. Step back! Niche dynamics in cave dwelling predators. Acta Oecologica, 75, 35-42. https://doi.org/10.1016/j.actao.2016.06.011

Mitchell, R.W., Reddell, J.R. (Eds.), 1973. Studies on the cavernicole fauna of Mexico and adjacent regions (Vol. 5). Bulletin of the Association for Mexican Cave Studies, 5.

Moseley, M., 2009. Size matters: scalar phenomena and a proposal for an ecological definition of cave. Cave and Karst Science, 35, 89-94

Novak, T., Perc, M., Lipovšek, S., Janžekovič, F., 2012. Duality of terrestrial subterranean fauna. International Journal of Speleology, 41 (2), 181-188. https://doi.org/10.5038/1827-806X.41.2.5

Oliver, I., Beattie, A.J., 1996. Invertebrate morphospecies as surrogates for species: a case study. Conservation Biology, 10, 99-109.

https://doi.org/10.1046/j.1523-1739.1996.10010099.x

Peck, D.V., Herlihy, A.T., Hill, B.H., Hughes, R.M., Kaufmann, P.R., Klemm, D.J., Lazorchak, J.M., McCormick, F.H., Peterson, S.A., Ringold, P.L., Magee, T., Cappaert, M., 2006. Environmental monitoring and assessment program - surface waters western pilot study: field operations manual for wadeable streams. EPA/620/R-06/003, US Environmental Protection Agency, Office of Research and Development, Washington, DC, USA.

Peel, M.C., Finlayson, B.L., McMahon, T.A., 2007. Updated world map of the Köppen-Geiger climate classification. Hydrology and Earth System Sciences, $11,1633-1644$.

https://doi.org/10.5194/hess-11-1633-2007

Pellegrini, T.G., Ferreira, R.L., 2012. Sampling effort in mite communities associated with cave bat guano. Speleobiology Notes, 4, 10-16.

Pellegrini, T.G., Ferreira, R.L., 2013. Structure and interactions in a cave guano-soil continuum community. European Journal of Soil Biology, 57, 19-26. https://doi.org/10.1016/j.ejsobi.2013.03.003

Pellegrini, T.G., Ferreira, R.L., 2016. Are inner cave communities more stable than entrance communities in Lapa Nova show cave? Subterranean Biology, 20, 15-37. https://doi.org/10.3897/subtbiol.20.9334

Pellegrini, T.G., Sales, L.P., Aguiar, P., Ferreira, R.L., 2016. Linking spatial scale dependence of landuse descriptors and invertebrate cave community composition. Subterranean Biology, 5, 1-9. https://doi.org/10.3897/subtbiol.18.8335

Platnick, N.I., Pass, G., 1982. On a new Guatemalan Pseudocellus (Arachnida, Ricinulei). American Museum novitates, no. 2733.

Poulson, T.L., Culver, D.C., 1969. Diversity in terrestrial cave communities. Ecology, 50, 153-158.

https://doi.org/10.2307/1934678

Prous, X., Ferreira, R.L., Jacobi, C.M., 2015. The entrance as a complex ecotone in a Neotropical cave. International Journal of Speleology, 44 (2), 177-189. https://doi.org/10.5038/1827-806X.44.2.7

Prous, X., Ferreira, R.L., Martins, R.P., 2004. Ecotone delimitation: epigean-hypogean transition in cave ecosystems. Austral Ecology, 29, 374-382.

https://doi.org/10.1111/j.1442-9993.2004.01373.x

$\mathrm{R}$ Core Team, 2019. R: A language and environment for statistical computing. R Foundation for Statistical Computing, Vienna, Austria. https://www.R-project.org/

Reddell, J.R., 1981. A Review of the cavernicole fauna of Mexico, Guatemala and Belize. The Texas Memorial Museum, 27, 327.

http://hdl.handle.net/2152/29949
Reddell, J.R., Veni, G., 1996. Biology of the Chiquibul cave system, Belize and Guatemala. Journal of Cave and Karst Studies, 58, 131-138.

Resende, L.P.A., Bichuette, M.E., 2016. Sharing the space: coexistence among terrestrial predators in Neotropical caves. Journal of Natural History, 50, 2107-2128

https://doi.org/10.1080/00222933.2016.1193641

Rodríguez, G., Hobbs, Jr. H.H., 1989. A new cavernicolous crab, Zilchia falcata, from Guatemala, with notes on the genera of the Potamocarcinini (Crustacea Decapoda, Pseudothelphusidae). Bulletin du Muséum national d'Histoire naturelle (Paris), 4, 183-192.

Santana, M.E.V., Souto, L.S., Dantas, M.A.T., 2010. Diversidade de invertebrados cavernícolas na Toca da Raposa (Simão Dias - Sergipe): o papel do recurso alimentar e métodos de amostragem. Scientia Plena, 6, 1-8.

Schneider, K., Christman, M.C., Fagan, W.F., 2011. The influence of resource subsidies on cave invertebrates: results from an ecosystem-level manipulation experiment. Ecology, 92, 765-776.

https://doi.org/10.1890/10-0157.1

Schultz, G.A., 1977. Two blind species, one new, of terrestrial isopod crustaceans (Oniscoidea: Philosciidae) from Yucatan and Guatemala. Bulletin of the Association of Mexican Cave Studies, 6, 9-13.

Sendra, A., Garay, P., Ortuño, V.M., Gilgado, J.D., Teruel, S., Reboleira, A.S.P.S., 2014. Hypogenic versus epigenic subterranean ecosystem: lessons from eastern Iberian Peninsula. International Journal of Speleology, 43 (3), 253-264. https://doi.org/10.5038/1827-806X.43.3.2

Simões, M.H., Souza-Silva, M., Ferreira, R.L., 2015. Cave physical attributes influencing the structure of terrestrial invertebrate communities in Neotropics. Subterranean Biology, 16, 103-121.

https://doi.org/10.3897/subtbiol.16.5470

Souza-Silva, M., Ferreira, R.L., 2009. Estrutura das comunidades de invertebrados em cinco cavernas insulares e intertidais na costa brasileira. EspeleoTema, 20, 25-36.

Souza-Silva, M., Martins, R.P., Ferreira, R.L., 2011 a. Trophic dynamics in a neotropical limestone cave. Subterranean Biology, 9, 127-138. https://doi.org/10.3897/subtbiol.9.2515

Souza-Silva, M., Martins, R.P., Ferreira, R.L., 201 1b. Cave lithology determining the structure of the invertebrate communities in the Brazilian Atlantic Rain Forest. Biodiversity Conservation. 20, 1713-1729. https://doi.org/10.1007/s10531-011-0057-5

Stein, A., Gerstner, K., Kreft, H., 2014. Environmental heterogeneity as a universal driver of species richness across taxa, biomes and spatial scales. Ecology Letters, $17,866-880$

https://doi.org/10.1111/ele.12277

Steinitz, O., Heller, J., Tsoar, A., Rotem, D., Kadmon, R., 2006. Environment, dispersal and patterns of species similarity. Journal of Biogeography, 33, 1044-1054. https://doi.org/10.1111/j.1365-2699.2006.01473.x

Strinati, P., 1994. Guatemala. In: Juberthie C., Decu V. (Eds.), Encyclopaedia Biospeologica. Société de Biospéologie, p. 437-442

Talley, T.S., 2007. Which spatial heterogeneity framework? Consequences for conclusions about patchy population distributions. Ecology, 88, 14761489. https://doi.org/10.1890/06-0555

Tews, J., Brose, U., Grimm, V., Tielbörger, K., Wichmann, M.C., Schwager, M., Jeltsch, F., 2004. Animal species 
diversity driven by habitat heterogeneity/diversity: the importance of keystone structures. Journal of Biogeography, 31, 79-92. https://doi.org/10.1046/j.0305-0270.2003.00994.x

Tobin, B.W., Hutchins, B.T., Schwartz, B.F. (2013). Spatial and temporal changes in invertebrate assemblage structure from the entrance to deep-cave zone of a temperate marble cave. International Journal of Speleology, 42 (3), 203-214.

https://doi.org/10.5038/1827-806X.42.3.4

Trontelj, P., 2019. Adaptation and natural selection in caves. In: White, W.B., Culver, D.C., Pipan, T. (Eds.), Encyclopedia of caves ( $3^{\text {rd }}$ Ed.). Academic Press, p. 40-46. https://doi.org/10.1016/B978-0-12-8141243.00006-6

Viana, A.C.M., Ferreira, R.L., 2019. A new troglobitic species of Typhloroncus (Arachnida: Pseudoscorpiones:
Ideoroncidae) from Guatemala. Zootaxa, 4576, 288300. https://doi.org/10.11646/zootaxa.4576.2.4

Wynne, J.J., Howarth F.G., Sommer S., \& Dickson B.G., 2019. Fifty years of cave arthropod sampling: techniques and best practices. International Journal of Speleology, 48 (1), 33-48.

https://doi.org/10.5038/1827-806X.48.1.2231

Zagmajster, M., Malard, F., Eme, D., Culver, D.C., 2018. Subterranean biodiversity patterns from global to regional scales. In: Moldovan, O.T., Kováč, L., Halse, S. (Eds.), Cave ecology, Springer, Cham, p. 195-227. https://doi.org/10.1007/978-3-319-98852-8_9

Zepon, T., Bichuette, M.E., 2017. Influence of substrate on the richness and composition of neotropical cave fauna. Anais da Academia Brasileira de Ciências, 89, 1615-1628.

https://doi.org/10.1590/0001-3765201720160452 